ISSN (Print) : 1693-0738

ISSN (Online) : 2714-5549

Innofarm:Jurnal Inovasi Pertanian Vol. 22 (1), April 2020

\title{
UJI KONSENTRASI TIGA MACAM PUPUK ORGANIK CAIR DARI LIMBAH PERTANIAN TERHADAP PERTUMBUHAN DAN HASIL TANAMAN ARUGULA (Eruca Sativa)
}

\author{
Sulistiawan Purnomo Aji", Siswadi, Saiful Bahri \\ Fakultas Pertanian, Universitas Slamet Riyadi, Surakarta \\ *E-mail: sulistiawanpurnomoaji@gmail.com
}

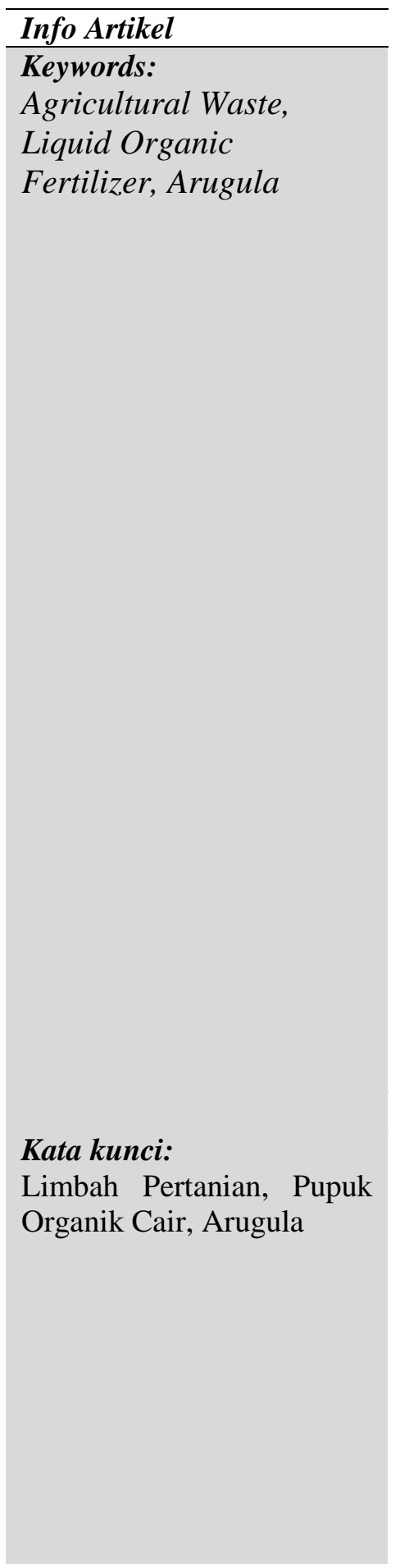

Abstract
This study is entitled Concentration Test of Three Liquid Organic
Fertilizer From Agricultural Waste on Growth and Yield of
Arugula (Eruca Sativa) to test the concentration of three kinds of
liquid organic fertilizer, sugarcane bagasse waste, banana peel
and coconut fiber with a concentration of 50 ml/l, 100 ml/l, and,
150 ml/l. This study uses a single Randomized Complete Design
(CRD) method consisting of 10 treatments that are repeated 3
times, consisting of K0, K1, K2, K3, K4, K5, K6, K7, K8, K9, the
results of this study were analyzed with Duncan's Multiple Range
Test (DMRT) at $5 \%$, the parameters observed were: plant height,
number of leaves, leaf width, leaf length, root length, fresh weight
of biomass, and dry weight of biomass. The results of the study
show that: (1) Giving treatment (K3), liquid organic fertilizer of
banana peels with a concentration of 150 ml/l, provides
interaction with parameters of observation of leaf width, root
length and dry weight of biomass arugula plants, but they need to
increase the concentration of organic fertilizer liquid to assist the
growth process with observations of plant height parameters,
number of leaves, leaf length and fresh weigh of biomass. (2)
Provision of treatment with 150 ml/l concentration is the best
treatment for the parameters of observation of leaf width, length
of root and dry weight of biomass, but the administration of 150
ml/l concentration is not sufficient for plant nutrient requirements
so there is no interaction with the growth process of plant height,
number of leaves, length of leaves and fresh weight of biomass.
(3) The highest dry weight of biomass in the treatment of liquid
organic fertilizer from banana peel waste with a concentration of
150 ml/l, weighing $4.32 \mathrm{~g}$ or an increase of $20 \%$ compared to the
control.

\section{Abstrak}

Penelitian ini berjudul Uji Konsentrasi Tiga MacampPupuk Organik Cair Dari Limbah Pertanian Terhadap Pertumbuhan Dan Hasil Tanaman Arugula (Eruca Sativa) dengan tujuan menguji konsentrasi dari tiga macam pupuk organik cair limbah ampas tebu, kulit pisang dan sabut kelapa dengan konsentrasi $50 \mathrm{ml} / \mathrm{l}$, $100 \mathrm{ml} / \mathrm{l}$, dan, $150 \mathrm{ml} / \mathrm{l}$. Penelitian ini menggunakan metode Rancangan Acak Lengkap (RAL) faktor tunggal yang terdiri 10 perlakuan yang diulang sebanyak 3 kali, terdiri dari : $\mathrm{K} 0, \mathrm{~K} 1, \mathrm{~K} 2$, $\mathrm{K} 3, \mathrm{~K} 4, \mathrm{~K} 5, \mathrm{~K} 6, \mathrm{~K} 7, \mathrm{~K} 8$, K9, Data hasil penelitian ini dianalisis dengan Uji Duncan's Multiple Range Test (DMRT) pada taraf $5 \%$, parameter yang diamati meliputi : tinggi tanaman, jumlah daun, lebar daun, panjang daun, panjang akar, berat brangkasan 


\begin{abstract}
segar dan berat brangkasan kering. Adapun hasil penelitian menunjukan bahwa : (1) Pemberian perlakuan (K3), pupuk organik cair kulit pisang dengan konsentrasi $150 \mathrm{ml} / \mathrm{l}$, memberikan interaksi terhadap parameter pengamatan lebar daun, panjang akar dan berat brangkasan kering tanaman arugula, namun perlunya penambahan konsentrasi pupuk organik cair untuk membantu proses pertumbuhan terhadap parameter pengamatan tinggi tanaman, jumlah daun, panjang daun dan berat brangkasan segar. (2) Pemberian perlakuan dengan konsentrasi $150 \mathrm{ml} / \mathrm{l}$ merupakan perlakuan terbaik terhadap parameter pengamatan lebar daun, panjang akar dan berat brangkasan kering, namun pemberian konsentrasi $150 \mathrm{ml} / \mathrm{l}$ belum mencukupi kebutuhan unsur hara tanaman sehingga tidak adanya interaksi pada proses pertumbuhan tinggi tanaman, jumlah daun, panjangxdaun dan beratcbrangkasan segar. (3) Berat brangkasan kering tertinggi pada perlakuan pemberian pupuk organik cair dari limbah kulit pisang dengan konsentrasi $150 \mathrm{ml} / \mathrm{l}$ yaitu seberat 4,32 $\mathrm{g}$ atau terjadi kenaikan sebesar $20 \%$ dibandingkan kontrol.
\end{abstract}

\title{
PENDAHULUAN
}

Limbah pertanian merupakan bahan basah atau kering dari hasil pertanian yang sudah dimanfaatkan potensi hasilnya baik untuk proses pengolahan hasil utama ataupun hasil sampingan, dari proses pengolahan tersebut menghasil limbah pertanian seperti limbah ampas tebu, kulit pisang dan sabut kelapa.

Menurut Marum et al., (2012), hasil samping industri gula di Indonesia berupa ampas (bagasse) sebesar 47,77 \% dan masih memiliki kandungan air 48-52\%. Limbah ampas tebu mengandung P2O5 (0,02\%), K2O (0,14\%), Ca (0,06\%), dan Mg (0,04\%) (BPP, 2002). Kandungan unsur organik dalam ampas tebu dapat diproses lebih lanjut sebagaiIpupukIorganikIcair.

Limbah kulit pisang yaitu limbah basah yang tidak dapat bertahan lama, apabila dibiarkan limbah kulit pisang akan membusuk dan memberikan bau yang tidak sedap. Hasil analisis Laboratorium Riset dan Teknologi Fakultas Pertanian Universitas Sumatera Utara, maka dapat diketahui bahwa kandungan unsur hara yang terdapat dalam kulit buah pisang kepok yaitu, $\mathrm{C}$-organik 6,19\%; N-total 1,34\%; P2O5 0,05\%; K2O 1,478\%; C/N 4,62\% dan pH 4,8. Unsur tersebut dapat dimanfaatkan sebagai pupuk organik cair.

Sabut kelapa salah satu limbah rumah organik yang jarak dilirik ataupun dimanfaatkan. Sabut kelapa mengandung $\mathrm{N}$ sebesar 2,366 \%, P sebesar 0,77\% dan $\mathrm{K}$ sebesar 0,41\%, (Waryanti, 2013), yang dapat dimanfaatkan sebagai pembuatan pupuk cair.

PupukLorganikucairsadalahalarutanadariahasilapembusukkan bahan-bahan organik yang berasal dari sisa bagian tanaman, kotoran hewan, dan manusia yang kandungan unsur haranya lebih dari satu unsur. Penggunaan pupukkorganikkcair dari limbah pertanian sangat tepat apabila digunakan pada komoditas tanaman sayuran. Salah satu komoditas tanaman sayuran juga termasuk tanaman herbal adalah tanaman arugula (Eruca Sativa).

Arugula berasal dari wilayah Mediterania, Lebanon, Suriah dan Turki, tanaman arugula dimanfaatkan sebagai bahan konsumsi, rasanya pahit dan sedikit pedas. Tanaman arugula juga merupakan tanaman herbal karna memiliki manfaat baik bagi tubuh seperti menurunkan kolesterol darah, membantu penderita diabetes dan dapat mencegah kanker. Di Indonesia tanaman arugula masih jarang dikenal oleh masyarakat, potensi tanaman arugula yang memiliki berbagai manfaat baik bagi kesehehatan tubuh sudah seharusnya dibudidayakan di Negara Indonesia. 


\section{BAHAN DAN METODE}

Rancangan percobaan yang digunakan dalam penelitian ini adalah Rancangan Acak Lengkap (RAL), faktor tunggal terdiri dari 10 perlakuan dan masing-masing perlakuan diulang 3 kali. Adapun perlakuannya sebagai berikut :
K0 : Kontrol
K5 : Limbah Ampas Tebu $100 \mathrm{ml} / \mathrm{l}$
K1 : Limbah Kulit Pisang $50 \mathrm{ml} / 1$
K6 : Limbah Ampas Tebu $150 \mathrm{ml} / \mathrm{l}$
K2 : Limbah Kulit Pisang $100 \mathrm{ml} / \mathrm{l}$
K7 : Limbah Sabut Kelapa $50 \mathrm{ml} / \mathrm{l}$
K3 : Limbah Kulit Pisang $150 \mathrm{ml} / \mathrm{l}$
K8 : Limbah Sabut Kelapa $100 \mathrm{ml} / \mathrm{l}$
K4 : Limbah Ampas Tebu $50 \mathrm{ml} / 1$
K9 : Limbah Sabut Kelapa $150 \mathrm{ml} / \mathrm{l}$

Untuk mengetahui pengeraruh perlakuan tersebut, digunakan Analisis Ragam. Analisis selanjutkan mengunakan uji Duncan's Multiple Range Test (DMRT) pada taraf 5\%, untuk mengetahui pengaruh masing - masing terhadap pemberian tiga macam pupuk organik cair dari limbah pertanian.

Bahan dan calat yang digunakan yaitu, (1) bahan : limbah ampas tebu, limbah kulit pisang, limbah sabut kelapa, cairan EM-4, gula pasir, air dan benih arugula. (2) alat : polybag, cangkul, timbangan, penggaris, meteran, ember, saringan kain, gelas ukur, gembor, alat tulis.

Penelitian ini di lakukan pada bulan Desember 2019 sampai dengan bulan Febuari 2020, dikebun percobaan (green house) Fakultas Pertanian Universitas Slamet Riyadi Surakarta, yang terletak di Jl. Jaya Wijaya No.238 Desa Mojosongo, Kecamatan. Banjarsari, Surakarta dengan ketinggian tempat \pm 143 meter dpl. Parameter pengamatan meliputi : parameter pengamatan tinggi tanaman dan jumlah daun diamati 1 minggu sekali, sementara parameter lebar daun, panjang akar, berat berangkasan segar dan berat brangkasan kering diamati saat tanaman arugula sudah dipanen.

\section{HASIL DAN PEMBAHASAN \\ PERTUMBUHAN TANAMAN ARUGULA}

Hasil pengamatan pertumbuhan tanaman arugula pada parameter pengamatan tinggi tanaman dan jumlah daun diamati setiap 1 minggu sekali yang disajikan pada tabel 1.

Tabel 1. Purata pertumbuhan arugula akibat uji konsentrasi tiga macam pupuk organik cair dari limbah pertanian

\begin{tabular}{ccc}
\hline Perlakuan & Tinggi Tanaman (cm) & Jumlah Daun (helai) \\
\hline K0 & $16.61 \mathrm{a}$ & $14,22 \mathrm{c}$ \\
K1 & $16.44 \mathrm{a}$ & $14,00 \mathrm{c}$ \\
K2 & $18.22 \mathrm{a}$ & $15.00 \mathrm{abc}$ \\
K3 & $18.23 \mathrm{a}$ & $19,67 \mathrm{a}$ \\
K4 & $16.06 \mathrm{a}$ & $14,11 \mathrm{c}$ \\
K5 & $16.72 \mathrm{a}$ & $15,89 \mathrm{abc}$ \\
K6 & $16.67 \mathrm{a}$ & $15,11 \mathrm{abc}$ \\
K7 & $16.28 \mathrm{a}$ & $13,23 \mathrm{c}$ \\
K8 & $16.39 \mathrm{a}$ & $14,28 \mathrm{bc}$ \\
K9 & $18.61 \mathrm{a}$ & $19,06 \mathrm{ab}$ \\
\hline
\end{tabular}

$\overline{\text { Keterangan : Angka yang diikuti huruf yang sama berarti tidak berbeda nyata pada uji Duncan pada }}$ taraf 5\% 


\section{Tinggi Tanaman}

Gambar 1. Grafik purata tinggi tanaman akibat uji konsentrasi tiga macam pupuk organik dari limbah pertanian $(\mathrm{cm})$

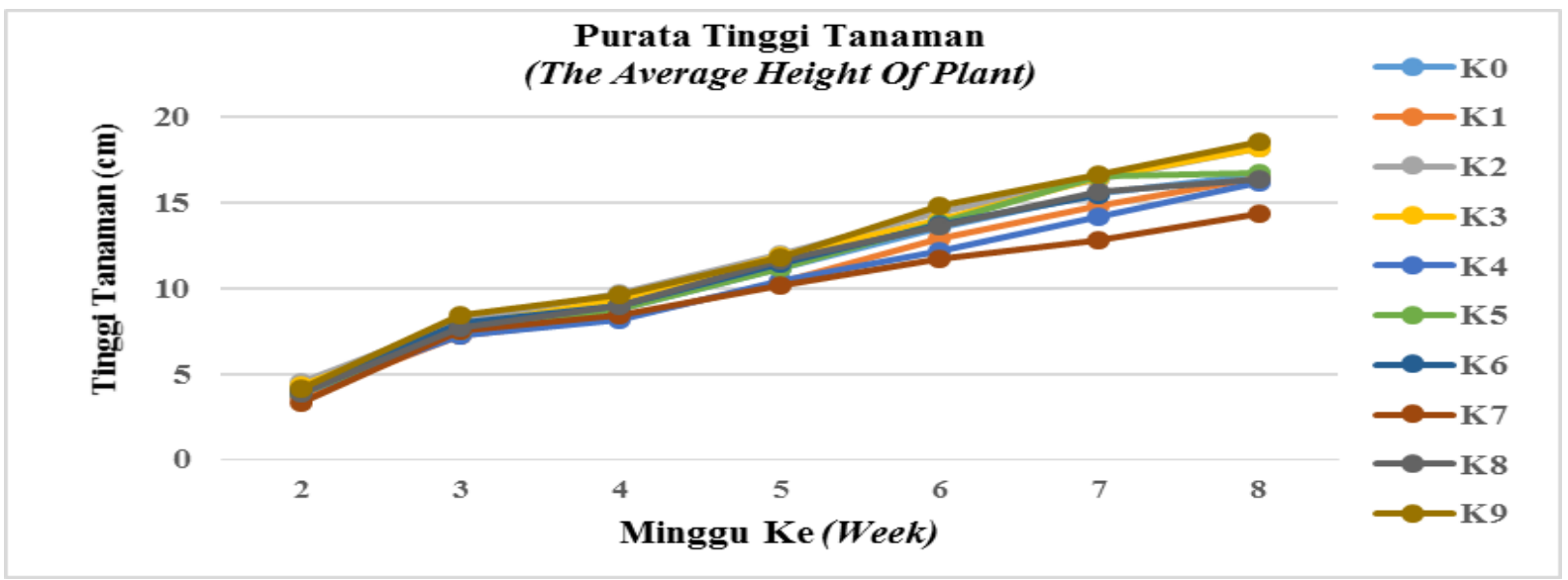

Berdasarkan gambar 1, diketahui bahwa pada grafik tinggi tanaman diantara perlakuan yang diberikan menunjukkan proses pertumbuhan tinggi tanaman yang seragam, pada hasil analisis ragam pemberian uji konsentrasi tiga macam pupuk organik cair menjunjukkan hasil yang berbeda tidak nyata terhadap tinggi tanaman.

Hasil table 1, menunjukkan bahwa diantara perlakuan yang diberikan konsentrasi tiga macam pupuk organik cair dari limbah pertanian menunjukkan hasil yang berbeda tidak nyata, jika dibandingkan dengan perlakuan kontrol tanpa pemberian pupuk organik cair (K0), terhadap parameter pengamatan tinggi tanaman. Hal tersebut diduga pemberian konsentrasi $50 \mathrm{ml} / \mathrm{l}$, atau $100 \mathrm{ml} / \mathrm{l}, 150$ $\mathrm{ml} / \mathrm{l}$, dari tiga macam pupuk organik cair dari limbah pertanian belum mencukupi kebutuhan unsur hara tanaman arugula. Pertumbuhan akan optimal jika unsur hara yang dibutuhkan tanaman tersedia dalam jumlah dan bentuk yang sesuai dengan kebutuhan tanaman (Sarief, 1989). Dalam proses pertumbuhan tinggi tanaman membutuhkan unsur utama salah satunya yaitu unsur $\mathrm{N}$ (Nitrogen). Unsur hara nitrogen berfungsi dalam pembentukan protein dan memperbaiki pertumbuhan vegetatif seperti tinggi tanaman dan jumlah daun (Hardjowigeno, 2003).

\section{Jumlah Daun}

Gambar 2. Histrogram purata jumlah daun umur 8 minggu akibat pemberian tiga macam pupuk organik cair dari limbah pertanian

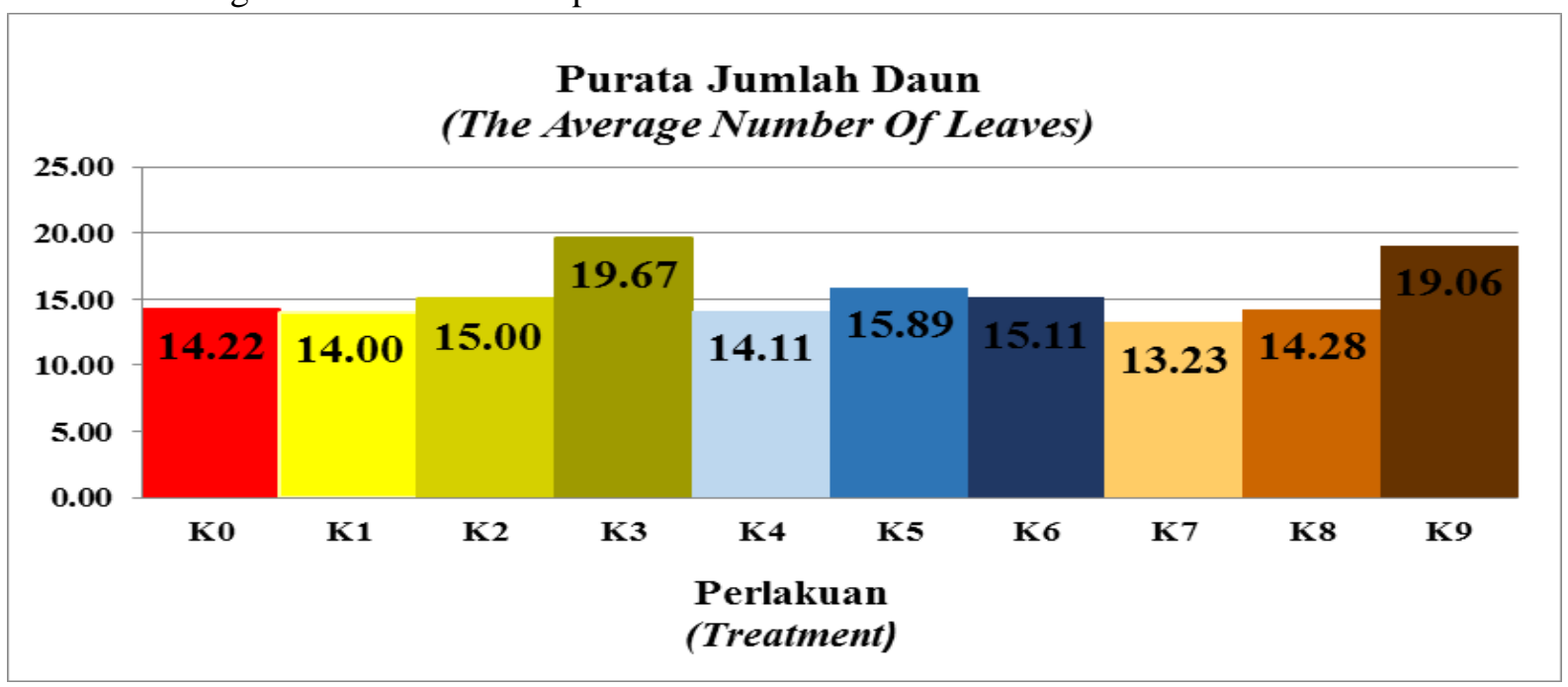

Sulistiawan Purnomo Aji, Siswadi, Saiful Bahri 
Berdasarkan gambar 2 diketahui bahwa nilai rata rata perlakuan dengan jumlah daun tertinggi pada perlakuan (K3), konsentrasi $150 \mathrm{ml} / \mathrm{l}$ menggunakan pupuk organik limbah kulit pisang dengan nilai rata rata jumlah daun 19.67 (helai), sementara nilai rata rata perlakuan jumlah daun terendah pada perlakuan (K7), konsentrasi $50 \mathrm{ml} / \mathrm{l}$ menggunakan pupuk organik cair limbah sabut kelapa dengan nilai rata rata jumlah daun 13.23 (helai).

Hasil dari tabel 1, menunjukkan bahwa pada perlakuan konsentrasi $150 \mathrm{ml} / \mathrm{l}$ menggunakan pupuk organik cair kulit pisang (K3), dengan nilai rata rata jumlah daun 19,67 (helai), berbeda nyata jika dibandingkan dengan perlakuan tanpa pupuk organik cair (K0), dengan nilai rata rata jumlah daun 14,22 (helai), hal ini disebabkan karna pupuk organik cair memiliki kandungan dua kali lipat sampai empat kali lipat dari kontrol.Pupuk organik cair dari limbah kulit pisang diduga memberikan pengaruh terhadap peningkatan fotosintesis sehingga meningkatkan pertumbuhan jumlah daun tanaman arugula. Pendapat ini sejalan dengan Latarang, dan Syakur, (2006). Pemberian pupuk kulit pisang dapat meningkatkan aktivitas fotosintesis yang digunakan tanaman.

\section{Hasil Tanaman Arugula}

Tabel 2. Purata hasil tanaman arugula akibat uji konsentrasi tiga macam pupuk organik cair limbah pertanian

\begin{tabular}{cccccc}
\hline Perlakuan & $\begin{array}{c}\text { Lebar Daun } \\
\mathbf{( c m )}\end{array}$ & $\begin{array}{c}\text { Panjang } \\
\text { Daun }(\mathbf{c m})\end{array}$ & $\begin{array}{c}\text { Panjang } \\
\text { Akar }(\mathbf{c m})\end{array}$ & $\begin{array}{c}\text { Berat } \\
\text { Brangkasan } \\
\text { Segar }(\text { gram })\end{array}$ & $\begin{array}{c}\text { Berat } \\
\text { Brangkasam } \\
\text { Kering }(\text { gram })\end{array}$ \\
\hline K0 & $4,49 \mathrm{e}$ & $11,50 \mathrm{c}$ & $21,94 \mathrm{c}$ & $27,78 \mathrm{~b}$ & $3,60 \mathrm{~cd}$ \\
K1 & $4,75 \mathrm{cde}$ & $12,23 \mathrm{abc}$ & $25,12 \mathrm{abc}$ & $28,09 \mathrm{~b}$ & $3,23 \mathrm{def}$ \\
K2 & $5,35 \mathrm{bc}$ & $12,87 \mathrm{abc}$ & $28,39 \mathrm{a}$ & $30,51 \mathrm{ab}$ & $3,92 \mathrm{abc}$ \\
K3 & $6,23 \mathrm{a}$ & $13,94 \mathrm{a}$ & $28,48 \mathrm{a}$ & $37,19 \mathrm{a}$ & $4,32 \mathrm{a}$ \\
K4 & $4,83 \mathrm{bcde}$ & $12,78 \mathrm{abc}$ & $24,02 \mathrm{bc}$ & $26,44 \mathrm{~b}$ & $3,11 \mathrm{f}$ \\
K5 & $5,22 \mathrm{bc}$ & $12,45 \mathrm{abc}$ & $25,96 \mathrm{bc}$ & $29,07 \mathrm{ab}$ & $3,56 \mathrm{cde}$ \\
K6 & $5,13 \mathrm{bcd}$ & $12,80 \mathrm{abc}$ & $26,11 \mathrm{ab}$ & $30,38 \mathrm{ab}$ & $3,67 \mathrm{bc}$ \\
K7 & $4,55 \mathrm{de}$ & $11,94 \mathrm{bc}$ & $25,89 \mathrm{ab}$ & $27,99 \mathrm{~b}$ & $3,20 \mathrm{ef}$ \\
K8 & $5,26 \mathrm{bc}$ & $12,81 \mathrm{abc}$ & $25,95 \mathrm{ab}$ & $31,93 \mathrm{ab}$ & $3,84 \mathrm{ab}$ \\
K9 & $5,50 \mathrm{~b}$ & $13,33 \mathrm{ab}$ & $28,50 \mathrm{a}$ & $32,02 \mathrm{ab}$ & $4,04 \mathrm{ab}$ \\
\hline Ke
\end{tabular}

Keterangan : Angka yang diikuti huruf yang sama berarti tidak berbeda nyata pada uji Duncan pada taraf $5 \%$

Tabel 2 merupakan purata hasil panen tanaman arugula yang meliputi parameter pengamatan lebar daun, panjang daun, berat brangkasan segar dan berat brangkasan kering. Pada hasil analisis ragam menunjukkan bahwa pemberian perlakuan dengan uji konsentrasi tiga macam pupuk organik cair dari limbah pertanian memberikan pengaruh terhadap parameter pengamatan lebar daun, panjang akar dan berat brangkasan kering, namun pada parameter pengamatan panjang daun dan berat brangkasan segar pemberian perlakuan uji konsentrasi tiga macam pupuk organik cair dari limbah pertanian tidak memberikan pengaruh terhadap parameter tersebut.

Tanaman arugula merupakan komoditas tanaman sayuran, bagian tanaman yang umumnya dimanfaatkan sebagai bahan konsumsi adalah daunnya. Di Negara berkembang daun tanaman arugula digunakan sebagai bahan campuran pada salad, burger, topping pizza, sandwitch dan taburan sup. Daun yang digunakan sebagai bahan konsumsi panjangnya tidak boleh melebihi dari $10 \mathrm{~cm}$, hal tersebut akan mempengaruhi rasa pahit dan pedas daun arugula. 


\section{Lebar Daun}

Gambar 3. Histrogram purata lebar daun akibat uji konsentrasi tiga macam pupuk organik cair dari limbah pertanian

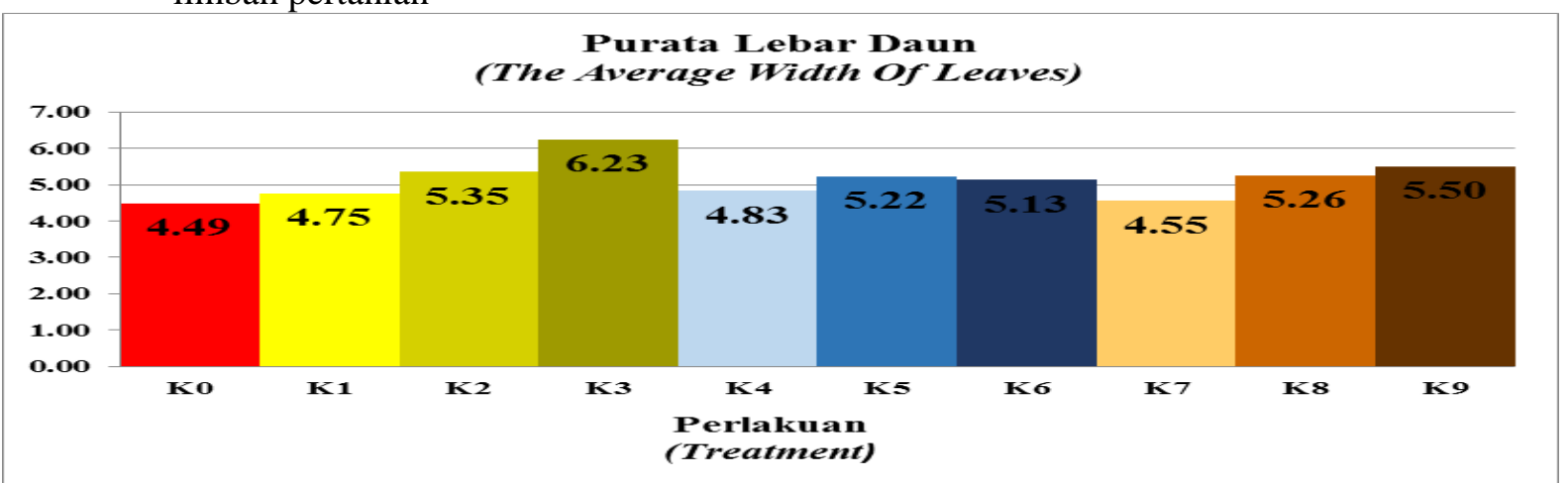

Berdasarkan gambar 3, pemberian perlakuan (K3), konsentrasi $150 \mathrm{ml} / \mathrm{l}$ menggunakan pupuk organik kulit pisang merupakan perlakuan dengan nilai rata rata lebar daun, tertinggi yaitu $6,23 \mathrm{~cm}$, hal ini diduga unsur N pada perlakuan (K3), dapat mencukupi kebutuhan tanaman arugula. Menurut pendapat Salisbury dan Ross (1995), menyatakan bahwa penyerapan unsur hara nitrogen berpengaruh terhadap pembentukan luas daun.

Pada tabel 1, menunjukkan hasil bahwa perlakuan (K3), memiliki nilai rata rata jumlah daun tertinggi tanaman arugula. Pengamatan secara visual terlihat daun tanaman arugula terlihat besar dan lebar. Menurut Rosmarkam dan Yuwono (2002), bahwa Nitrogen merupakan hara makro yang utama yang sangat penting untuk pertumbuhan tanaman, hal ini terbukti dengan adanya fungsi dari nitrogen meningkatkan kualitas tanaman yang menghasilkan banyaknya pertumbuhan luas daun.

Manfaat unsur nitrogen yaitu meningkatkan pertumbuhan tanaman, memproduksi klorofil, meningkatkan kadar protein, dan mempercepat tumbuh daun. Klorofil dibutuhkan pada proses fotosintesis. Umumnya klorofil disintesis pada daun dan berperan untuk menangkap cahaya matahari yang jumlahnya berbeda-beda tiap spesies (Marviana \& Utami, 2014). Oleh sebab itu, semakin luas permukaan daun maka intensitas sinar matahari yang diterima semakin besar, dan klorofil pada daun yang berfungsi menangkap energi matahari akan meningkatkan laju fotosentesis sehingga semakin banyak karbohidrat yang dihasilkan untuk pembelahan sel dan menyebabkan daun tumbuh lebih besar dan lebar (Uminawar, et al., 2013).

\section{Panjang Daun}

Gambar 4. Histrogram purata panjang daun akibat uji konsentrasi tiga macam pupuk organik cair dari limbah pertanian $(\mathrm{cm})$

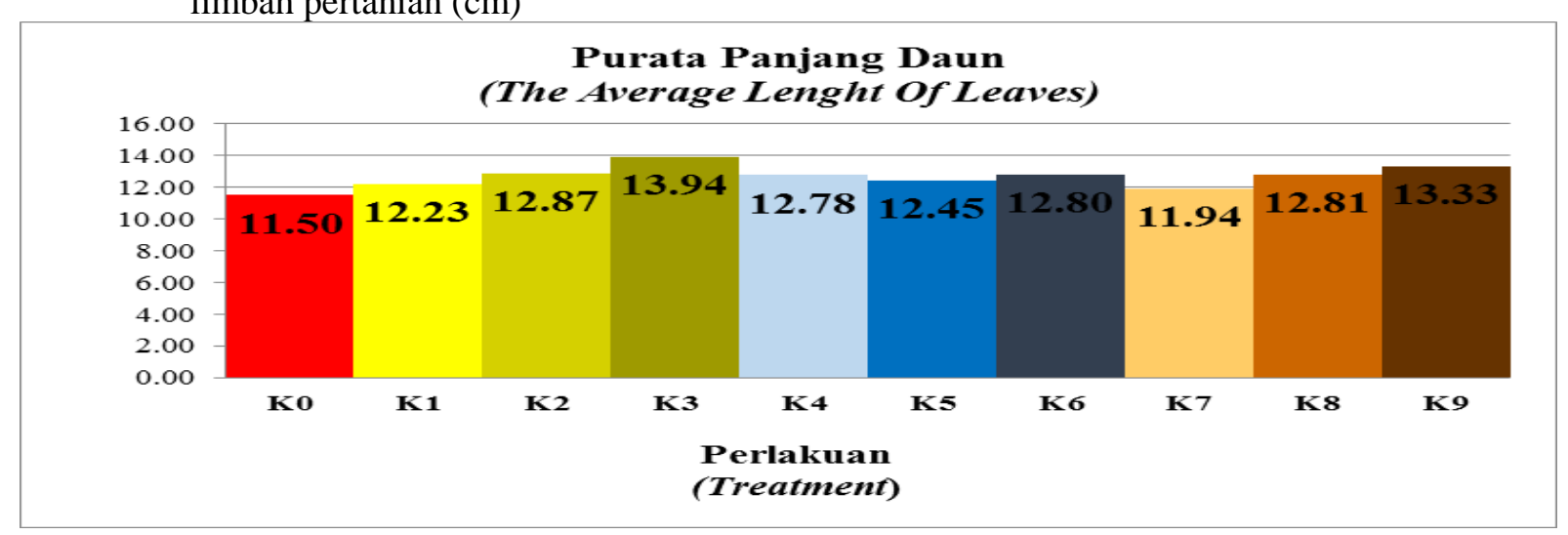


Berdasarkan gambar 3, perlakuan (K3), dengan konsentrasi $150 \mathrm{ml} / \mathrm{l}$ menggunakan pupuk organik cair limbah kulit pisang merupakan perlakuan dengan nilai rata rata tertinggi terhadap panjang daun tanaman arugula yaitu $13,94 \mathrm{~cm}$. Hal tersebut dikarnakan pertumbuhan tanaman arugula pada perlakuan konsentrasi $150 \mathrm{ml} / \mathrm{l}$ menggnakan pupuk organik kulit pisang (K3), mendapatkan nilai ratarata tertinggi dari pengamatan jumlah daun, (tabel 1) dan lebar daun, (tabel 2,), jika dikaitkan dengan panjang daun tanaman arugula, maka dapat diduga bahwa semakin baik pertumbuhan vegetatif tanamanan pada jumlah daun dan lebar daun maka akan mempengaruhi proses pembentukan sel pada panjang daun.

Pertumbuhan panjang daun berkaitan erat dengan pertumbuhan tunas. Apabila pertumbuhan panjang tunas lebih cepat maka jumlah daun akan ikut berpengaruh, demikian terjadi sebaliknya. Edmon, et al,. (1983), menjelaskan bahwa jika tanaman memiliki sumber karbohidrat dan nitrogen dalam jumlah yang besar dan didukung oleh faktor lingkungan yang mendukung, maka tanaman akan memperlihatkan pertumbuhan panjang daun.

\section{Panjang Akar}

Gambar 5. Histrogram purata panjang akar akibat uji konsentrasi tiga macam pupuk organik pupuk organik cair dari limbah pertanian $(\mathrm{cm})$.

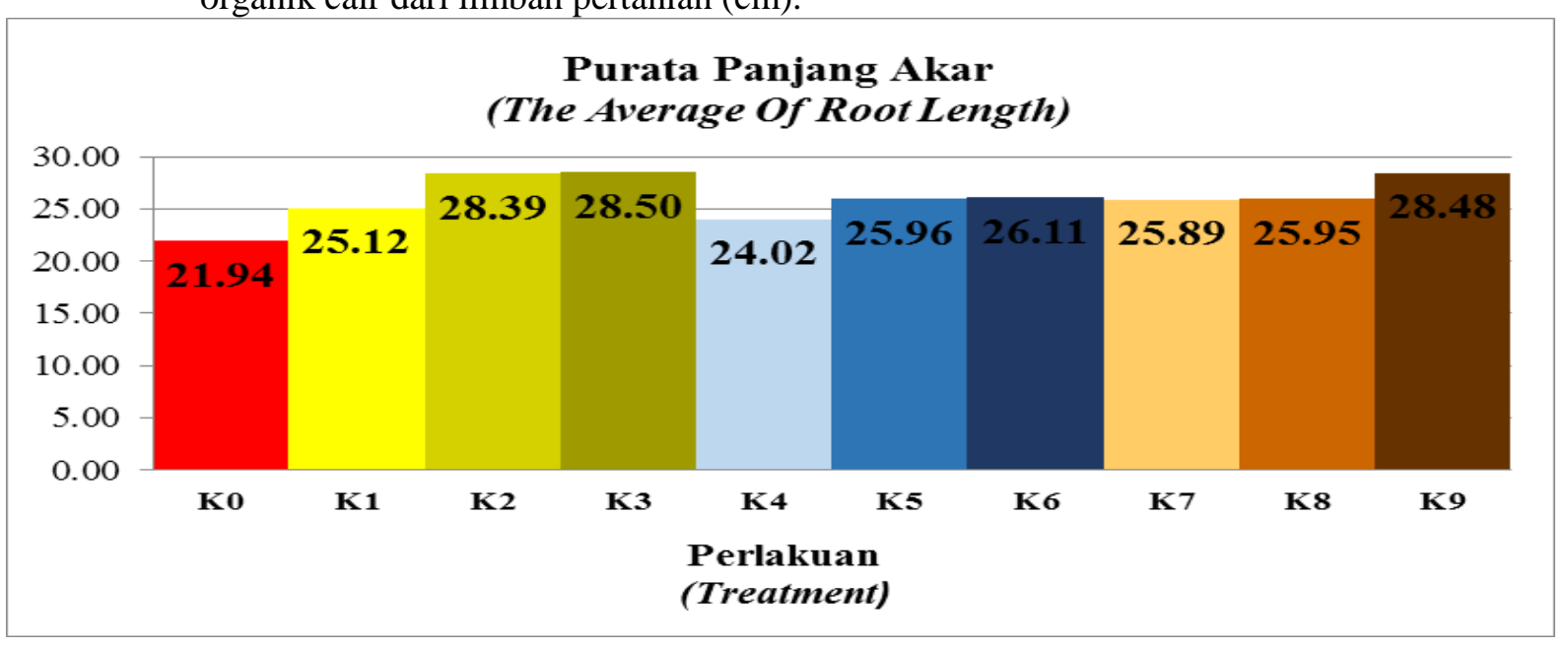

Berdasarkan gambar 5, nilai rata rata panjang akar tertinggi pada perlakuan konsentrasi 150 $\mathrm{ml} / \mathrm{l}$ menggunakan pupuk organik sabut kelapa (K9), dengan nilai rata rata panjang akar $28.50 \mathrm{~cm}$. Hal tersebut diduga unsur hara yang terkandung dalam pupuk organik cair sabut kelapa adalah kalsium yang berperan pada titik-titik tumbuh seperti pucuk muda dan ujung akar (Suripto, et al,. 2018). Pendapat Prawoso (2001), dalam Jamilah, et al,. (2013), juga menjelaskan bahwa kandungan unsur hara yang terdapat dalam sabut kelapa, yaitu: air P53,83\%, N 0,28\% ppm, P 0,1 ppm, K 6,726 ppm, Ca 140 ppm, dan Mg 170 ppm. Menurut pendapat Sarief (1989), bahwa unsur kalium merupakan salah satu dari beberapa unsur utama yang diperlukan tanamanldan sangat mempengaruhi tingkat produksi tanaman. 
ISSN (Print) : 1693-0738

ISSN (Online) : 2714-5549

Innofarm:Jurnal Inovasi Pertanian Vol. 22 (1), April 2020

\section{Berat Brangkasan Segar}

Gambar 6. Histrogram purata panjang akar akibat uji konsentrasi tiga macam pupuk organik pupuk organik cair dari limbah pertanian $(\mathrm{cm})$.

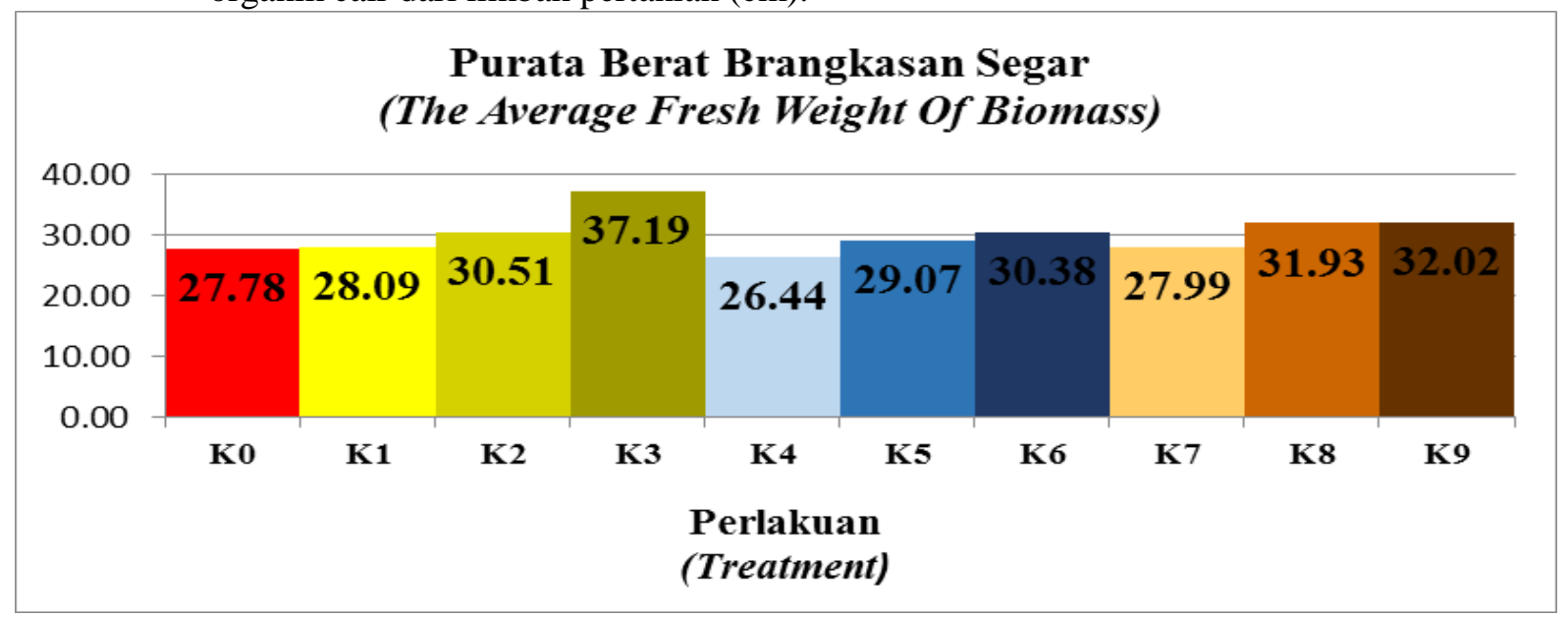

Nilai rata rata berat brangkasan segar tertinggi pada perlakuan (K3), dengan konsentrasi 150 $\mathrm{ml} / \mathrm{l}$ menggunakan pupuk organik cair limbah kulit pisang dengan nilai rata rata berat brangkasan segar 37,19 g, berbeda nyata jika dibangingkan dengan perlakuan (K4), konsentrasi $50 \mathrm{ml} / \mathrm{l}$ menggunakan pupuk organik cair limbah ampas tebu dengan nilai rata rata berat brangkasan basah $26,44 \mathrm{~g}$. Hal ini diduga unsur nitrogen digunakan dalam membentuk senyawa yang penting bagi proses fotosintesis dan proses pembelahan sel. Karbohidrat dihasilkan oleh daun sebagai hasil proses fotosintesis dapat menstimulir pembentukan organ-organ baru (Hakim, 2009).

\section{Berat Brangkasan Kering}

Gambar 7. Histrogram Purata Berat Brangkasan Kering akibat uji konsentrasi tiga macam pupuk organik cair limbah pertanian.

\section{Purata Berat Kering Brangkasan (The Average Dry Weight Of Biomass)}

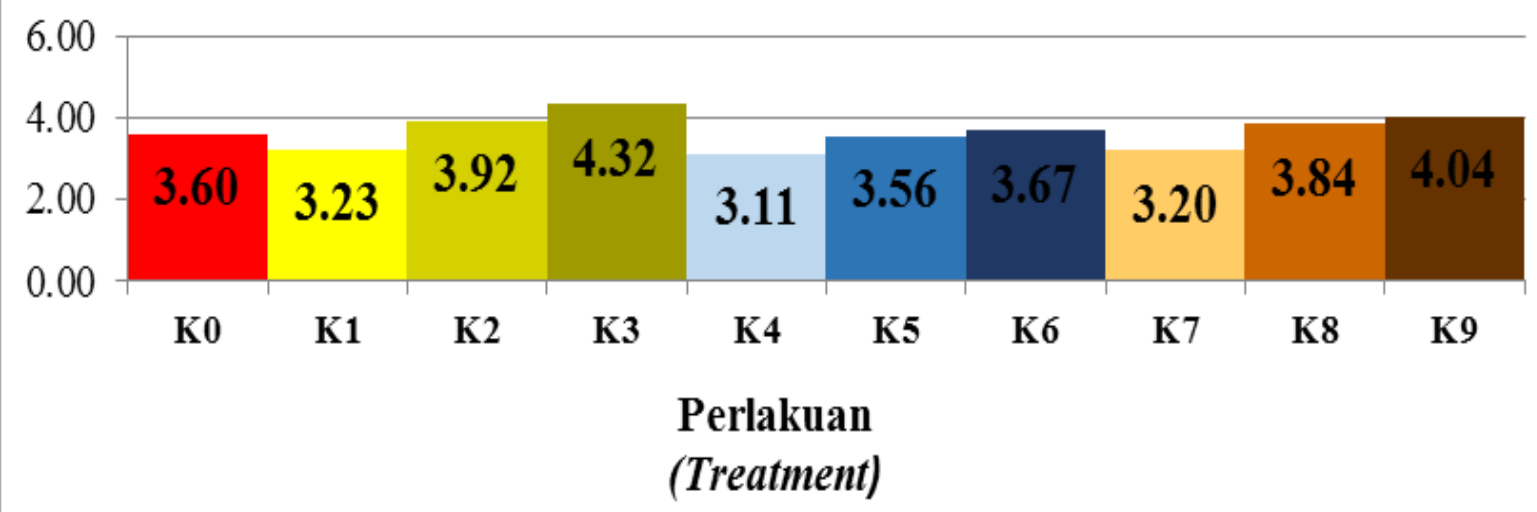

Pada tabel 7 dapat dilihat bahwa perlakuan (K3), dengan konsentrasi $150 \mathrm{ml} / \mathrm{l}$ menggunakan pupuk organik cair limbah kulit pisang merupakan perlakuan dengan nilai rata rata tertinggi terhadap berat brangksan kering yaitu seberat 4,32 g dan terjadi kenaikan seberat $20 \%$, jika dibandingkan dengan perlakuan (K0) tanpa pupuk organik cair dengan berat berangkasan seberat 3,60 g. 
Berat brangkasan kering mencerminkan akumulasi senyawa organik yang berhasil di sintesis tanaman dari senyawa organik terutama air dan karbohidrat. Unsur hara yang telah diserap akar digunakan dalam sintesa senyawa organik maupun yang tetap dalam bentuk ionik dalam jaringan tanaman dalam akan memberikan kontribusi terhadap pertumbuhan berat kering tanaman

\section{KESIMPULAN}

Berdasarkan hasil penelitian dari perlakuan Uji Konsentrasi Tiga Macam Pupuk Organik Cair Dari Limbah Pertanian Terharap Pertumbuhan Dan Hasil Tanaman Arugula (Eruca Sativa). Dapat diambil kesimpulan sebagai berikut :

1. Pemberian perlakuan (K3), pupuk organik cair limbah kulit pisang dengan konsentrasi $150 \mathrm{ml} / \mathrm{l}$, memberikan interaksi terhadap parameter pengamatan lebar daun, panjang akar dan berat brangkasan kering tanaman arugula, namun perlunya penambahan konsentrasi pupuk organik cair untuk membantu proses pertumbuhan terhadap parameter pengamatan tinggi tanaman, jumlah daun, panjang daun dan berat brangkasan segar.

2. Pemberian perlakuan dengan konsentrasi $150 \mathrm{ml} / \mathrm{l}$ merupakan perlakuan terbaik terhadap parameter pengamatan lebar daun, panjang akar dan berat brangkasan kering, namun pemberian konsentrasi $150 \mathrm{ml} / \mathrm{l}$ belum mencukupi kebutuhan unsur hara tanaman sehingga tidak adanya interaksi pada proses pertumbuhanstinggi tanaman, jumlah daun, panjang daun dan berat brangkasan segar.

3. Berat brangkasan kering tertinggi pada perlakuan pemberian pupuk organik cair dari limbah kulit pisang dengan konsentrasi $150 \mathrm{ml} / \mathrm{l}$ seberat 4,32 g atau terjadi kenaikan sebesar $20 \%$ dibandingkan kontrol.

\section{DAFTAR PUSTAKA}

Badan Penelitian dan Pengembangan PT. Gula Putih Mataram. 2002. Hasil Analisis Bagase, Blotong, dan Abu. PT. Gula Putih Mataram. Lampung.

Edmon, J. B.,T.C. Senn, F.S. Andrew and R.G. Halfacre. 1983. Fundamental Of Horticulture. $4^{\text {th }}$ Ed., Mc. Graw Hill Publ.,Co.,Ltd., New Delhi.

Hakim, A. M. (2009). Asupan nitrogen dan pupuk organik cair terhadap hasil dan kadar vitamin C kelopak bunga rosela (hisbiscus sabdariffa l.). Universitas Sebelas Maret, Surakarta.

Hardjowigeno, S. 2003. Klasifikasi Tanah dan Pedegenesis. Jakarta : Akademika Pressindo. 250 hal

Jamilah, Yopi Napitupulu dan Yunis Marni. 2013. Peranan Gulma Chromoleanaodorata dan Sabut Kelapa sebagai Bahan Baku Pupuk Organik Cair Menggantikan Pupuk Kalium untuk Pertumbuhan dan Hasil Padi Ladang. Padang: Fakultas Pertanian Universitas Taman Siswa Padang.

Latarang, dan Syakur. 2006. Pengaruh Pemberian Bahan Organik Terhadap Pertumbuhan dan Produksi Bawang Merah. Jurnal Hort. 5.

Marum, J., D. Zulfita dan Mulyadi. 2012. Pengaruh kompos ampas tebu terhadap pertumbuhan dan hasil tanaman lobak pada tanah podsolid merah kuning. Program Studi Agronomi Universitas Tanjungpura. Hal:1-16.

Marviana, D. D. \& Utami, L. B. 2014. Respon pertumbuhan tanaman terung (solanum mlogena. l.) terhadap pemberian kompos berbahan dasar tongkol jagung dan kotoran kambing sebagai materi pelajaran biologi versi kurikulum 2013. Jurnal Penelitian Mahasiswa Pendidikan Biologi, 1(1), 161-166. 
ISSN (Print) : 1693-0738

ISSN (Online) : 2714-5549

Innofarm:Jurnal Inovasi Pertanian Vol. 22 (1), April 2020

Rosmarkam, A dan N. W. Yuwono. 2002. Ilmu Kesuburan Tanah. Kasinus, Yogyakarta.

Sarief Saifuddin, 1989. Kesuburan dan Pemupukan Tanah Pertanian. PT. Pustaka Buana. Bandung.

Suripto Widagdo, Tyas Purwani, dan Bambang Nugroho. 2018. "Pengaruh Konsentrasi Pupuk Organik Cair Sabut Kelapa terhadap Pertumbuhan dan Hasil Kentang Kleci" Seminar Nasional Dalam Rangka Dies Natalis UNS Ke 42 Tahun 2018, Yogyakarta.

Uminawar, Umar, H. \& Rahmawati. (2013). Pertumbuhan semai nyatoh (palaquiumsp.) pada berbagai perbandingan media dan konsentrasi pupuk organik cair di persemaian. Jurnal Warta Rimba, 1(1), 1-9.

Waryanti, anik. 2013. "Studi Pengaruh Penambahan Sabut Kelapa Pada Pembuatan Pupuk Cair Dari Limbah Air Cucian Ikan Terhadap Kualitas Unsur Hara Makro (CNPK)". Jurnal teknologi. Vol 8 (3), $40-41$. 